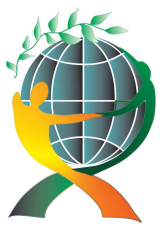

\author{
(online) $=$ ISSN $2285-3642$ \\ ISSN-L = $2285-3642$ \\ Journal of Economic Development, Environment and People \\ Volume 6, Issue 1, 2017
}

URL: http://iedep.spiruharet.ro

e-mail: office jedep@spiruharet.ro

\title{
Methodological Framework for ex-ante Assessment of Active Policies on the Labor Market - Experimental Approach
}

\author{
Daniela Pașnicu ${ }^{1}$, Gabriela Tudose ${ }^{2}$ \\ ${ }^{1}$ Universitatea Spiru Haret/ Institutul Național de Cercetare Științifică în Domeniul Muncii și Protecției \\ Sociale \\ ${ }^{2}$ Institutul Național de Cercetare Științifică în Domeniul Muncii și Protecției Sociale
}

\begin{abstract}
Ex-ante assessment is a mandatory step before the process of implementation of policies because it brings, through the analyses undertaken improvements for initial design, contributing, on a case by case basis, to increasing of efficiency, effectiveness, relevance, sustainability, equity and of its internal and external coherence. In recent years, at international level, but especially in the EU countries (EU), the ex-ante socio-economic programs and public interventions have become an extremely necessary instrument in decision-making, which is linked own economic and social development of the EU Member States.

The article presents a methodological framework for ex-ante assessment of active measures for the employment growth in the context of rural areas, on the bases of efficiency, effectiveness and coherence criteria. Ex-ante social impact assessment of an active policy can have beneficial effects on employment under quantitative and qualitative aspects. The novelty of the article consist in the specific, experimental approach of the development and of ex-ante evaluation of active labor market policies, in the context of rural areas.
\end{abstract}

Keywords: ex-ante assessment; active policies; labor market; social impact; rural area

JEL Codes: J08; J43

\section{Introduction}

Over the past few years, in EU countries, ex-ante evaluation of socio-economic impact of public intervention programs has become extremely necessary in decision-making. Ex-ante evaluation represent an impact analysis, by means of which is desired effects assessment that a public policy implementation have. This type of assessment is a mandatory step before the implementation of a public policy in the view of successfully achievement of objectives. This stage enables readjustment of measures, through the elements of improvement which it emits, representing an integral part in process of formulating and implementing of public policies.

Depending on the stage in the which intervenes, ex-ante evaluation has a key role in: 1) choosing active policy alternatives; 2) calibration and readjustment of the design of the active policy developed in the first phase, in manner to have a logic of intervention well-articulated and to bring real contribute to fulfill 


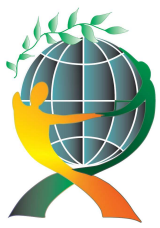

\author{
(online) $=$ ISSN $2285-3642$ \\ ISSN-L = $2285-3642$ \\ Journal of Economic Development, Environment and People \\ Volume 6, Issue 1, 2017 \\ URL: $\underline{\text { http://iedep.spiruharet.ro }}$ \\ e-mail: office jedep@spiruharet.ro
}

targets of increase the employment in terms of quantity and quality; 3 ) establishing mechanisms for subsequent development of the monitoring and evaluation functions in the event of policy implementation.It is therefore necessary that all active labor market policies to be supported by an ex-ante assessment.

Ex-ante evaluation must be oriented towards a goal which bring quality of life, prosperity and new opportunities for citizens. Makers responsible for policy planning together with professionals try to anticipate, using different quantitative and qualitative study methods, the impact on society as a result of policy implementation [1]. Better coordination of policies, both within Member States and at European level too, implies that the social impact of policy initiatives to be more carefully evaluated to minimize potential negative social consequences, through measures targeted on providing opportunities and reduce poverty. E.U. strengthened its objective to improve the capacity of member countries to carry out assessments of ex-ante, social impact assessment respectively, by promoting good governance, transparency and increasing stakeholder involvement in the design, implementation and monitoring of policies.

This article aims to investigate problems related to: the conceptual delimitation of the term of ex-ante evaluation; ex-ante evaluation phases; ex-ante evaluation criteria; tools and methods for ex-ante impact of active measures in the context of outlining specific elements for the ex-ante evaluation of active labor market policies in rural areas. An implicit component of our approach to ex-ante evaluation was setting limits thereof, as a result of factors generally valid.

Methodological elements presented in the article resulting from the analysis of patterns of social impact assessment of the literature [2], [3], [4], [5] and the authors' experience gained in a research project [6], which will be described briefly in the following section. Partial results achieved in the project, such as: the main structural deficiencies on the rural labor market and quality employment; increasing the quality of employment in rural areas through education adapted to the labor market requirements; social business models in the context of Romanian rural environment, have been presented at scientific conferences [7], [8], [9]. The results obtained in this work process can be, by adapting specific elements, an important methodology for ex-ante evaluation of the impact of active labor market policy with beneficial effects on employment growth.

\title{
2. Project description
}

The main goal of the project "System of measures to increase the employment-oriented rural population" is to develop a robust scientific substantiation of the proposed measures for increasing employment rate in rural areas. The specific objectives are: 1 . Development of the SWOT analysis of the rural employment; 2 . Formulation of a set of active measures aimed to increase the rural employment rate focused on the transfer of labor from the field of subsistence agriculture to the field of non-agricultural activities with added value, with growth and competitiveness potential, as well as focused on the entrepreneurship development; 3 . Ex-ante assessment of the effects of the active measures proposed on the basis of efficiency, effectiveness and coherence criteria. In the first phase of the project were proposed ten measures to increase rural employment and of these could be assessed ex ante only five. Their exclusion was justified, presenting the constraints and limitations specific to each measure, depending on 


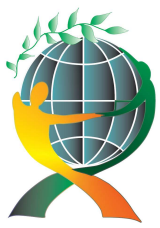

\author{
(online) $=$ ISSN $2285-3642$ \\ ISSN-L = $2285-3642$ \\ Journal of Economic Development, Environment and People \\ Volume 6, Issue 1, 2017 \\ URL: $\underline{\text { http://iedep.spiruharet.ro }}$ \\ e-mail: office jedep@spiruharet.ro
}

its characteristics. This article will present the steps that led to the fulfilment of the third objective of the project mentioned above.

At the public policies level were outlined three types of impact: economic, social and environmental, which can vary in intensity from one policy to another [10]. In the literature there is no universally accepted definition of what constitutes "social" effects. The most social effects may be limited to the following types of impact, namely: i. Employment (including rights standards and the labor market); ii. revenues; iii. access to services (health, education, social services, etc.); iv. respect for fundamental rights (including equal opportunities); v. public health and safety [11]. Given this classification, scientific approach in this article focuses on the features ex-ante evaluation of the social impact of active policies on employment. The main criteria on which the ex-ante assessment of social impact is made are: efficiency, effectiveness and coherence (internal and external). Among the specific techniques we can mention the following: SWOT analysis, micro-simulation technique (MS), macro-economic modelling, case studies, analysis of causality, experiment, etc. At the end of the article are presented some constraints, general limitations that the evaluation team had to take into account.

\title{
3. Ex-ante evaluation stages of an active policy on the labor market in rural areas
}

Assessing the impact of policy measures involves collecting, processing, analysing and processing data, which means establish a scientific research tool for reaching it. Good assessment requires consideration of several factors that can modify the design of initially proposed measure, namely:

1. Variations of component policies involved;

2. Variations in inputs used;

3. Variations for different time scenarios.

\subsection{Identifying needs and social problems in rural areas}

To achieve a qualitative ex-ante evaluation of impact of a measure / policy the issues should be more clearly and accurately defined, in a comprehensive way and justifying with data the appropriate to intervene in the labor market. Identified problem shows the need for public intervention and the proposed measure represent its materializing.

To identify existing problems in the rural labor market was delimited investigated area, was established limits of statistical indicators used in subsequent analyses and performed an analysis of the general characteristics of rural areas, disparities, gaps and development potential. This analysis was structured on two levels: 1) the delimitation of the economic and social importance of rural development and 2) investigation of major structural deficiencies facing it. The importance of developing rural areas and agriculture was highlighted by contributing in a determining manner to the following objectives: restoring economic growth at nationally level, ensuring food security and safety, conservation and protection of natural resources, favourable food balance (and payments) and increasing Romanian food exports, poverty reduction and improved quality of life, alternative green energy sources, etc.

Investigation of structural weaknesses faced by rural supposed systematic analysis of the following aspects: the structure of the national economy and human capital on each activity sector, the structure and dynamics of farms and quality of financial and technological rural domestic capital. 


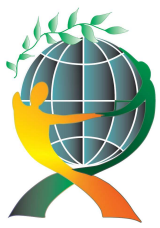

\author{
(online) $=$ ISSN $2285-3642$ \\ ISSN-L = $2285-3642$ \\ Journal of Economic Development, Environment and People \\ Volume 6, Issue 1, 2017 \\ URL: http://iedep.spiruharet.ro \\ e-mail: office jedep@spiruharet.ro
}

To complete the above described procedures, were carried out two further analysis, in-depth regarding: a) legislative and institutional framework regarding the rural areas in Romania in terms of employment and b) socio-economic characteristics of rural areas.

The analysis of the legislative and institutional framework regarding the rural areas in Romania in terms of employment, which focused on three levels: the strategic framework of Romania in the EU policies context, programs and rural development measures or which affect the development of the rural areas; financing instruments of the policies, programs and rural development measures or which have an impact on the rural development and the institutional framework on rural development.

The identification process of the main policy approach on employment in the Romanian rural areas started from the analysis of the Government Programme and Partnership Agreement 2014-2020 for development and investment in Romania (PA 2014-2020); it was followed by examining the European strategies (the Strategy for smart, sustainable and inclusive growth - Europe 2020, the Cohesion Policy and the Common Agricultural Policy) under which were structured the national program of governance and the strategic documents in force at the reporting date; and it ended with the analysis of the planning/programming documents at national level (National Reform Programme 2015, National Rural Development Programme 2014-2020, Human Capital Operational Programme 2014-2020, National Strategy for Employment 2014-2020, National Strategy for Competitiveness 2014 - 2020, National Sustainable Development Strategy of Romania Horizons 2013-2020-2030, The Romanian National Climate Change Strategy 2013 - 2020, The Government Strategy on Development of Small and Medium-Sized Enterprises and Improvement of the Business Environment in Romania - Horizon 2020).

Analysis of socio-economic characteristics of the rural areas which covered a range of relevant statistical indicators for rural areas in relation to the degree of development and economic competitiveness; demographic trends; employment and unemployment growth. Three categories of indicators were analysed: economic context indicators (gross domestic product (GDP), gross value added (GVA), gross fixed capital formation (GFCF), labor productivity in agriculture, the number of people employed in agriculture, the annual income per farming family of workers, the monthly average net nominal wage earnings per total economy and agriculture); demographic indicators (resident population by sex in the rural areas, the demographic dependency ratio, school population, domestic and international migration flows); indicators on the labor market (active population, inactive population, the activity rate, the inactivity rate, people discouraged from looking for a job, employed population, job vacancies, rate of job vacancies in agriculture, the number of unemployed and the unemployment rate etc.). The statistics were as sources: National Institute of Statistics Romania (INS), Eurostat, The Common Agricultural Policy (CAP) indicators, etc.

\title{
3.2. Identification and describing in an intermediate form of the active policy
}

The analyzes undertaken in the first stage that had a decisive role in identifying issues will also form an important basis for describing the active policy. This step was performed to further analyze the potential for employment in rural areas, to collect in-depth information that was not available, on certain vulnerable groups, in statistical databases, needed for identification and description of the measure tailored to labor market needs of rural area. Analysis of the employment potential in the rural area from Romania was achieved through a quantitative research - households' survey. This sub-stage targeted collection and 


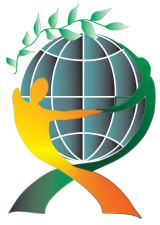

\author{
(online) $=$ ISSN $2285-3642$ \\ ISSN-L = $2285-3642$ \\ Journal of Economic Development, Environment and People \\ Volume 6, Issue 1, 2017 \\ URL: http://iedep.spiruharet.ro \\ e-mail: office jedep@spiruharet.ro
}

interpretation of data, related to: socio-demographic household members, employment in rural areas, labor market and employment services in rural areas, opportunities for employment growth, satisfaction with public services, causes which impeding the development of municipalities, corresponding risks of climate change, income and expenditure in rural households, household activities, labor migration. The sample included 1,070 respondents, representative of both households and the heads of household or respondents in a maximum error of $\pm 3 \%$ at a confidence level of $95 \%$. The sample was designed to be layered on seven development regions (not included in the sample Bucharest-llfov region), probabilistic (random selection of villages and households) and multistage.

The results of this survey that was taken into account in the design / ex-ante assessment of measures reflect actuality of rural employment, confirming and complementing previous analyzes. These results relate to: the character of work in rural areas, the degree of satisfaction with the current job, the availability to geographical and occupational mobility, the degree of addressability of public employment services (PES), poor efficacy of active employment measures promoted by PES, lack of employment opportunities and "ease" with which it comes in long-term unemployment, expectations of rural people on minimum wages that would like to get a job, the current situation on labor market for those with low levels of training, which in significant percentage hold a job with no future, that weak sought locally, unattractively and lack of interest in terms of courses and retraining, especially for older workers, the unemployed, including long-term unemployed and in particular the unemployed people seeking first job, day laborers, unpaid family workers and housekeepers, farmers/workers on their own; need for diversification of agricultural activity, the importance of non-agricultural economy, creation quality jobs, the need to diversify the service sector and rural infrastructure development etc.

The analyzes were completed with a SWOT analysis of rural employment which aimed to characterize brief, real and profound employment in rural areas, thus creating an instrument of scientific support and management necessary design, implementation and ex-ante assessment of measures aimed at employment in rural areas.

Among the categories of information required for a proper description, materializing of the active policy include:

- Name

- Justification

- The institutional framework

- The legal framework

- Objectives

- Beneficiaries

- The target group (participants)

- The period of time of action

- Risks and opportunities

- Measurement indicators (outcome and impact indicators)

- Sources of funding 


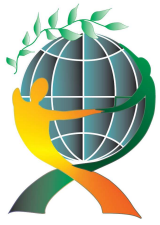

\author{
(online) $=$ ISSN $2285-3642$ \\ ISSN-L = $2285-3642$ \\ Journal of Economic Development, Environment and People \\ Volume 6, Issue 1, 2017 \\ URL: http://iedep.spiruharet.ro \\ e-mail: office jedep@spiruharet.ro
}

\title{
3.3. Evaluation of reason and active policy consistency
}

This stage is the essence of the ex-ante assessment as it involves complex issues of interconnection and the basis for appropriate formulating of active policy. To determine the reason of the policy must be taken of its objectives and priorities. Consistency should be evaluated by analysing the relationships and complementarity between the priorities of the measure, particularly in the case of integrated active policies. Also in this stage must consider the potential risks and opportunities that may arise following the implementation of the measure and how they can be minimized, maximized respectively. Ex-ante evaluation should explore and weigh the balance between the standard measures that are easy to implement, and those that are riskier but have a greater impact.

In designing measures in a form which is appropriate to the needs identified in relation to the characteristics of the target groups to be addressed in full compliance with investment programs and economic development of the rural areas it was necessary an exercise of their validation through an qualitative investigation.

Thus, a first evaluation of active reason and consistency of the policies proposed to increase employment in rural areas was carried out by analysis of perceptions of key experts / stakeholders at the local level on issues investigated. This qualitative assessment was performed by in-depth interviews that led to the validation / improvement the preliminary set of measures to increase rural employment. It has a sample of specialists consists of 28 people from the 7 development regions (except Bucharest-Ilfov region) and in 16 counties. The four categories of respondents - representatives of county agencies for employment, NGOs, Local Action Groups (LAGs) and municipalities were selected to cover a wide range as high as aspects of issues investigated. The research methodology was based on using an interview guide structured on two levels, who watched: 1) expression of popular opinion on employment in rural areas, the main disadvantaged groups in the labor market in rural areas, measures taken locally versus necessary measures in the view of respondents, the local development strategy and development priorities; 2) assessment of actual each measure proposed, aiming at obtaining useful information regarding: perceived usefulness, institutions may charge, potential sources of financing, risks and opportunities, pros and cons opinions. The results of the qualitative analysis showed the justice of measures proposals, the respondents' perception of their being generally positive. Five of measures have met in a greater consensus but it should be noted the consensus of respondents to support the measures under assessment. This shows firstly the very need for intervention in rural areas as diverse and complex measures to cover potential diversity of existing target groups. However, respondents pointed permanent that such measures are only effective if they are coupled with measures to invest in infrastructure development in rural areas and in health services and education.

\subsection{Establishing criteria for ex-ante assessment}

There are several criteria for ex-ante, among them: relevance; effectiveness; efficiency; impact; sustainability, consistency, community involvement, equity [12]. Ex-ante evaluation of the measures proposed in the project described above was made on the basis of three criteria: coherence, effectiveness and efficiency. 


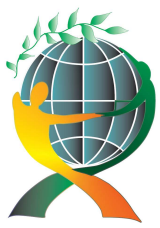

\author{
(online) $=$ ISSN $2285-3642$ \\ ISSN-L = $2285-3642$ \\ Journal of Economic Development, Environment and People \\ Volume 6, Issue 1, 2017 \\ URL: http://iedep.spiruharet.ro \\ e-mail: office jedep@spiruharet.ro
}

Internal and external coherence is a specific evaluation criterion that refers to structure policy and financial allocation for its implementation, namely its relation to other policies regional, national or Community. All measures were analyzed in terms of internal and external coherency.

In assessing internal coherency were the following aspects: coherence of the measure structure, coherence of the intervention lines and of their logic array; overlaps or contradictions within the measure that may arise especially in integrated measures case; consistency of financial allocations.

Regarding the external coherence, a major importance have the strategic guidelines at regional, national, European. In the case of active policies for employment growth in rural areas, an important role play policies, programs and measures in Romania and the EU referring to rural development. External coherence of the proposed measures with strategies, programs, policies that relate to rural development in Romania and the EU was assessed in terms of objectives, results and financial allocations.

Effectiveness is the extent to which policy achieves its objectives. The degree to which the results meet the needs identified in the design phase. It is a measure of the effectiveness of policies.

Efficiency consider a further aspect, essential in implementing projects and programs, namely finance. Moreover, efficiency takes into account the following aspects:

- It could have obtained the same results with fewer resources?

- Unit costs are too high?

- Even if the objectives are achieved, the project / program too expensive to be continued?

\title{
3.5. Outcome and impact assessment
}

The methods used for ex-ante assessment in terms of efficiency and effectiveness are specific to each measure. Of quantitative and qualitative techniques used in the project, remarked:

- econometric analysis both at the macroeconomic level, the panel, and at the micro level;

- micro-econometric approach has considered micro-simulation technique which was followed by shaping behavior in the absence and presence of micro units of measure proposed for insertion in the labor market;

- analyses and normative scenarios;

- case study;

- causal analysis;

- inquiry-based focus group;

- SWOT analysis

A very important part of any ex-ante methodology is to establish a set of indicators and databases for quantification. The set of indicators is determined by the desired impact to be evaluated and the evaluation criteria. Mention may be two broad categories of indicators: financial and physical. Intake of data necessary for the ex-ante active policy on the labour market may come from statistical databases at national or international level or own database, collected by various methods and tools.

In evaluating the results and impact of active policies, it has a key role in gathering information derived from analyzes conducted in rural areas, in the early stages, namely, analysis of socio-economic 


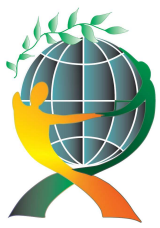

\author{
(online) $=$ ISSN $2285-3642$ \\ ISSN-L = $2285-3642$ \\ Journal of Economic Development, Environment and People \\ Volume 6, Issue 1, 2017 \\ URL: http://iedep.spiruharet.ro \\ e-mail: office jedep@spiruharet.ro
}

characteristics, analysis of the legal and institutional frameworks, quantitative and qualitative analysis, SWOT analysis.

Among the sources which were at the basis of ex-ante analysis, providing a history of the effects of applying the provisions that support employment in rural area, mention: Law regulations. 72/2002; SAPARD program; I RDP in the period 2007 - 2013; NEA reports, etc.

\title{
3.6. Evaluation of the proposed implementation system including the mechanisms for the subsequent monitoring and evaluation functions
}

Detailing the measure must contain elements of the provisions implementing, including the designation of bodies and procedures for the implementation of the monitoring and evaluation, partnership agreements, procedures for advertising and the exchange of computerized data to meet the payment requirements for the implementation of the measure. The quality of these systems is essential for implementing the objectives. At this stage, assessing implementing provisions proposed for managing, monitoring and evaluation. In doing this, it would be considered examination of previous experience, possible bottlenecks which might impede implementation of the measure and should make recommendations for preventive action. It would also assess the quality and extent of partnership arrangements.

\subsection{Recommendations for alternative actions}

Following ex-ante evaluation of each measure, the steps above, making recommendations for corrections to improve the design of the original measure so that its implementation to provide maximum employment opportunities for the beneficiary. Value recommendations is given both, the rigor of following steps of the ex-ante assessment and evaluators experience in implementing active labor market policies.

\subsection{Development of an ex-ante assessment report on active labor market policy}

The final report should include a summary of the measure active social impact assessment, methodological issues, key findings, corrections made and the final design of the measure.

\section{Limits of ex-ante analysis}

The choice of methods for ex-ante assessment depends on the nature of the effects to be assessed (economic, social and environmental); the criteria by which the assessment is made and data availability (structure, the period of time for implementation, length data series, etc.). A problem that arises in the research process is the uncertainty regarding certain information. There are situations where scientific data / statistics available may be missing altogether (Davies, 2004).

Ex-ante evaluation of the new measures are achieved too, based on the results of similar programs and measures under the current application. The assessor is able to rely on the experience of the current programming period (for example, by mid-term evaluation) and previous programming periods (the expost) to improve the design and implementation of new programs.

Another problem is the existence of weaknesses in the monitoring of the measures already implemented, which could be an important source of data for ex-ante evaluation of the proposed new measures. Mention of these shortcomings: some of the selected indicators for the construction of data 


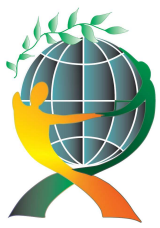

\author{
(online) $=$ ISSN $2285-3642$ \\ ISSN-L = $2285-3642$ \\ Journal of Economic Development, Environment and People \\ Volume 6, Issue 1, 2017 \\ URL: http://iedep.spiruharet.ro \\ e-mail: office jedep@spiruharet.ro
}

series (which led to the conception evaluation of econometric models) of monitoring reports are presented by different characteristics; some data are presented only at the aggregate level without being broken down by residence, counties (e.g. spending on active measures not settled in the residence); the data aren't sufficiently structured on the active measure characteristics and participant (ex. civil employed population by occupational status and county etc.); variations in data collection methodologies, etc. Thus, the research team had to resort to analyzing existing contextual data, to estimate/calculate the missing data. In situations where the available data are initially insufficient can be used case studies or pilot experiments designed to collect specific information.

The success of ex-ante evaluation of measures, including in terms of risks and opportunities, is dependent of the awareness by the assessor too, on the part of the existing problem and the environment to which it belongs, of the legal, institutional framework of the implementation measure, and on the other side of its evaluation methodology. The evaluator must take into account, in the allocation of public resources, the opportunity cost of choosing a specific action / intervention judging rationally based on advantages and disadvantages of other ways of resources allocation. In other words, to consider the existence of an alternative action that can achieve better results for the individual, firm, society with the same resources, using another type of intervention. Also, the evaluator should consider the opportunity cost of choosing affordability measure by the beneficiary in material and time resources allocation of the beneficiary of the active measure.

Having regard to the above mentioned, it becomes essential for the success of any effort being assessed and coordinated operational information system and continuously updated.In. An ex-ante assessment well done can contribute to more efficient use of available funds, to enhance the effectiveness and relevance of the intervention, and time optimize of active measure implementation.

\title{
5. Conclusions
}

Ex-ante evaluation is an integral part in the formulation and implementation of public policies. It is necessary for any public policy to be supported by an ex-ante assessment, especially if new measures where success is not guaranteed, and implementation is not always an easy task. When applied properly, ex-ante assessment can help to cope with complex socio-economic situation, full of uncertainties, unmanageable. Its purpose is to remove some unwanted issues that may arise in the implementation of the measure. For example, designing a tool to improve employment prospects for a population group can have negative consequences for others.

It requires synergy and complementarity with other rural development programs. Implementation of active policy to increase employment must be in tandem with carrying out investment plans at local, regional and sectoral level, investment in physical capital coupled with the human capital for to achieve a critical mass of economic growth and development socio-economic parameters.

At the U.E country level they were identified as the main obstacles on the ex-ante social impact assessment: discrepancies between quantitative targets for research and qualitative nuances of reality; lack of appropriate tools, methodologies and data sources for the quantitative assessment of the social impact; social impact assessment is often performed by public servants who are not familiar with social policies, 


\author{
(online) $=$ ISSN $2285-3642$ \\ ISSN-L = $2285-3642$ \\ Journal of Economic Development, Environment and People \\ Volume 6, Issue 1, 2017 \\ URL: http://iedep.spiruharet.ro \\ e-mail: office jedep@spiruharet.ro
}

feeling the lack of written guidelines; training and formation of ad hoc technical assistance; limited resources advice to those involved in the assessment processes.

\title{
6. References
}

[1] S. Briggs, B. Petersone, S. Karlis, Manual de metode folosite în planificarea politicilor publice și evaluarea impactului, 2006, pg.17

[2] R. Antonie, Social Impact Assessment Models, Transylvanian Review of Administrative Sciences, pp. 22-29, No. $29 \mathrm{E} / 2010$.

[3] J.D. Birckmayer, C.H. Weiss, Theory-Based Evaluation in Practice, Evaluation Review, vol.24, no. 4, pp. 407-43, 2003.

[4] R.Blaine, S. Worthen, R. James, L. Fitzpatrick, Program Evaluation: Alternative Approaches and Practical Guidelines, 4th Edition, 2011.

[5] European Commission, Evalsed - Sourcebook- Method and Techniques, 2013, EVALSED

[6] Project "System of Measures to increase employment of the rural Population" developed, within the Sectorial Plan R\&D of MMFPSPV for period 2013-2015, Priority direction "Development and adequacy policies of employment and continuing vocational training to economic cyclicality" program Labour Market,under the financing agreement no. 6/2015, by INCSMPS, CURS partner, Daniela Pasnicu coordinator.

[7] D. Pasnicu, G. Tudose (2016) The Main Structural Deficiencies on the Rural Labour Market and Employment Quality, WLC 2016 - World LUMEN Congress. Logos Universality Mentality Education Novelty 5th Anniversary Edition, The European Proceedins of Social and Behavioural Sciences EpSBS, eISSN: 2357-1330

[8] D.Pașnicu, G.Tudose Social business models in the context of Romanian rural environment, International Conference on Economic Sciences and Business Administration (ICESBA 2016), Procedia of Economics and Business Administration - ISSN 2392-8174, ISSN-L 2392-8166, 2016

[9] D.Pașnicu, G. Tudose, Increasing the quality of employment in rural areas through the education adapted to labor market requirements, 9th annual International Conference of Education, Research and Innovation - ICERI,14-16 November, ICERI 2016 Proceedings, ISBN: 978-84-617-5895-1.

[10] Unitatea de Politici Publice, Secretariatul General al Guvernului, Manual pentru elaborarea Propunerii de Politici Publice, 2006

[11] European Commission, Impact Assessment Guidelines, January 2009.

[12] European Commission, Guidance Document on Ex-ante Evaluation. The Programming Period 2015-2020, Monitoring and Evaluation of European Cohesion Policy, 2014. 